\title{
Springs as a Civilizing Mechanism in Daphnis and Chloe
}

\begin{abstract}
In Longus' Daphnis and Chloe, springs are a central motif of the Prologue and the novel as a whole. This motif counters male domination, since it is associated with Chloe, while the flowers watered by springs in this novel are identified with Daphnis. This study will examine how the motif of springs reflects the resistance of Daphnis and Chloe to pervasive cultural constructions of gender, creating individuals who participate in the larger society without reproducing its structures.
\end{abstract}

Given the progression of Longus' novel toward a normative marriage of a heterosexual couple of the same socioeconomic status, interpreters of Daphnis and Chloe have often focused on the motifs that teach the characters how to comport themselves according to societal expectations. Epstein stresses the narrative's association of Daphnis, Pan, and goats. ${ }^{1}$ Morgan suggests that Longus 'naturalizes' gender inequalities by depicting males as promiscuous and females as submissive in a pastoral setting. ${ }^{2}$ As Chalk and Winkler have noted, Longus evinces a realistic awareness about the dangers of both the patriarchal and pastoral. ${ }^{3}$ Indeed, this might be seen in the narrative's concern for the voices of the nightingales and the echo, originally women who suffered male violence. I will propose, however, that the social critique of Daphnis and Chloe continues past identifying the consequences of gender-based violence and into providing an erotic alternative to the sexual relationships that disenfranchised Procne, Philomela, and Echo. Throughout the novel, Longus' healing of the relations between the sexes is associated with springs. In the ideal grove of the Prologue, a single spring sustains the whole complex, and this presages the function of 'real' springs - that is, springs located on the island of Lesbos - in the novel as a whole. The spring establishes gender equality by providing a location for alternative cultural definitions of 'civilization': it is the site where Daphnis and

1 Epstein 2002, 72.

2 Morgan 2004, 12.

3 Chalk 1960, 46; Winkler 1990.

Janelle Peters, University of St. Francis (Illinois)

https://doi.org/10.1515/9781501503986-011 
Chloe begin and defend their reciprocal relationship against threats from romantic rivals and militaristic invaders. Chloe, who thinks her ablution of Daphnis in the spring of the Nymphs has rendered him kalos, successfully avoids having either Dorkon or Daphnis abduct her or take her virginity, and in each instance this happens beside a spring in the woods. Daphnis, as Epstein has stated, learns to avert his animalistic impulses in a way that his rival Dorkon does not. ${ }^{4}$ After the relationship is ratified by the ruling elite of Mitylene, Daphnis and Chloe ground their relationship in the spring and the goats that nourished them in their youth: they decorate the spring of the Nymphs and introduce the cult to their children. Through their connection with the spring, Daphnis and Chloe live in the city without being of the city.

In proposing that the spring provides Daphnis and Chloe with an enfranchising but still alternative romantic relationship, I posit that Longus pushes against patriarchal hegemony both within his social context and within his choice of narrative mode. The Second Sophistic was a time of cultural flux, latent with possibilities for alternate social constructions, as society was changing. ${ }^{5}$ Moreover, Konstan has shown that the ancient Greek novel differentiates itself from New Comedy in terms of romantic relationships: whereas New Comedy reinscribes patriarchal control over would-be adulterous wives and men of lower social status, the ancient Greek novel champions the passive hero in order to create sexual symmetry. ${ }^{6}$ In constructing his novel, then, Longus uses a sexually symmetrical pair whose innocence enables them to critique literary commonplaces they are too naïve to know that they should be taking rhetorical tropes seriously, and so the unnaturalness of Greek cultural attitudes is revealed. De Certeau has labeled this type of literary phenomenon 'social delinquency' and sees it as a strategy of cultural critique:

Social delinquency consists in taking the story literally, in making it the principle of physical existence where a society no longer offers to subjects or groups symbolic outlets and expectations of spaces, where there is no longer any alternative to disciplinary falling-intoline or illegal drifting away, that is, one form or another of prison and wandering outside the pale. ${ }^{7}$

It is precisely the text's ridiculous demand to take cultural conventions literally as though they really were natural - that allows Longus to construct a romantic

\footnotetext{
4 Epstein 1995.

5 Goldhill 1995, 2; Perkins 1995, 124; Boyarin 1997, 7.

6 Konstan 1994, 7.

7 De Certeau 1984, 130.
} 
novel that extricates its protagonists from the maenad/basilinna (anti-wife/ queen) dichotomy inherent in Dionysiac rituals in ancient Greek society. ${ }^{8}$

Longus chooses the spring of the Nymphs in particular to create an alternate Dionysiac religious practice: the spring creates a local idiom through such praxis as the offerings of first fruits of wine and of the syrinx. These rituals restore the songs of the nightingales, who perfect their laments. From Ovid's description of the myth of Philomela and Procne, we know that this was already connected with Dionysiac ritual. ${ }^{9}$ Longus' novel reconfigures the Dionysiac symbolic universe to highlight the voices in society that need to be tuned after neglect and abuse. This can be seen again in Philetas' garden, when the god Love possesses a silvery laugh like 'no swallow, no nightingale, no swan grown old' $(2,5,1)$, thus encompassing both women and men. The religious matrix of Longus' novel seeks to give a voice to the vulnerable couple and, presumably, the vulnerable reader.

Though the prologue has begun with a pleasure garden, the incipit of Book

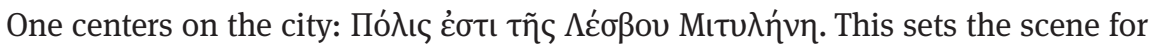
a tension between spring and city throughout the novel. As MacQueen has argued more broadly of the pastoral setting, the spring acts as a 'buffer' ${ }^{10}$ Ultimately, no broad social reform will be effected, but Daphnis and Chloe will experience a reciprocal relationship through ethics flowing from the springs of the novel. Their relationship will be sanctioned through the approval of the entire elite in Mitylene. Since the elite are summoned to recognize Chloe's birth tokens in response to Dionysophanes' dream, Daphnis and Chloe's relationship may be assumed to be authorized at both divine and mortal levels (4,34,1-2).

\section{Springs}

Springs feature prominently in Daphnis and Chloe, as they do on the island of Lesbos. ${ }^{11}$ In the Prologue, Longus describes the historia of the scene in a painting as being dependent upon the spring: 'a single spring sustained everything, flow-

8 For recent discussions on the pervasiveness of these dichotomies in Greek culture, see Seaford 1995, 301-11; Goff 2004, 278; Gilhuly 2009, 185. Social delinquency is a different notion than Bakhtin's novelistic hybridity that exists where different languages are brought together in order to critique each other. In Longus's Daphnis and Chloe, the same language, that of conventional erotic imagery, is consistently misread or not perceived. On novelistic hybridity, see Bakhtin 1981, 361; Burrus 1995, 51.

9 Ovid, Met. 6,587-605; 6,645-646; Burkert 1983, 181.

10 MacQueen 1990, 166.

11 Mason 1995, 263; Vieilleford 1987, 200. 
ers and trees alike'. The repetition of features from the Prologue's garden portrait communicates the pastoral message of Daphnis and Chloe. Froma Zeitlin has argued that the gardens of rustic scholar Philetas and urban elite Dionysophanes 'are precisely situated at crucial moments in the narrative as sequential models of the children's erotic development'. ${ }^{12}$ As the site of Eros, springs are at the center of the gardens of the novel and the heart of the relationship of the young lovers. The spring in the grotto of the Nymphs, where Chloe was abandoned as an infant, is the primary spring of the novel. This spring permits Daphnis and Chloe to bathe in each other's sight $(1,12-13 ; 1,32)$. Chloe washes Daphnis in the spring after the Methymnean raid $(2,18)$. Moreover, the trees and the vegetation of gardens can be taken elsewhere - for triumphal processions, for example - in ways that springs cannot. ${ }^{13}$ When Chloe is abducted by pirates beside the spring, Daphnis falls asleep at the spring and receives a dream revelation from the Nymphs $(2,23,1) .{ }^{14}$ At their transition from pastoral to civilized life, Daphnis and Chloe dedicate their most prized possessions at the spring. ${ }^{15}$ Daphnis drinks from the spring, and Chloe pours wine into it $(4,32,3)$.

Other springs in the novel reinforce the civilizing associations of the spring in the Grotto of the Nymphs. First, the lovers wash Dorkon in the spring where the goats drink after his attempted rape of Chloe $(1,21,4)$. Second, the garden of Philetas has three springs that sustain it and cleanse him $(2,3,4 ; 2,5,4)$. Third, Lykainion leads Daphnis to a spring hidden in the woods $(3,17,1)$. She suggests that Chloe should bathe in the spring after Daphnis takes her virginity. The narrative then skips to the virgin Chloe bathing in springs while Daphnis swims in rivers $(3,24,2)$. Fourth, when Lamon receives word that his master will be coming at the beginning of Book Four, his first act is to clean the springs in the park $(4,1,3)$. The authorial voice proceeds to describe the abundance of flowers supported by the spring and the Dionysiac temple at the center of the paradeisos $(4,2,6) .{ }^{16}$ This repeats the association of spring, garden, and Nymphs at the beginning of the novel. A spring reserved for flowers is deemed Daphnis' spring $(4,4,1)$.

12 Zeitlin 1990, 421.

13 Kuttner 1999a, 345.

14 Dream revelations in Second Temple period Jewish literature often occur while the prophet is asleep at the river (Dan. 10,9; 1 Enoch. 13,7-8). See Peters 2009, 133. In Daphnis and Chloe, the first dream revelation (that of the parents) envisages the spring $(1,7,2)$, the second (that of Daphnis) occurs at the spring, and the third (that of captain Bryaxis) is near the sea $(2,27-28)$. Beginning with the third book, the dream revelations come in response to conscious anxieties of the dreamers and use legitimating description that convinces the dreamer to act unconventionally (e.g., abandoning refined education for shepherding).

15 Zeitlin 1990, 443.

16 Zeitlin 1990, 451. 
Longus' motif of the spring subverts the natural landscapes, the loci amoeni, found in critics of luxury. In authors such as Horace and Lucretius, these idyllic environments are minimally defined by elements of water, trees, and song. ${ }^{17}$ Horace sets such places of natural beauty in opposition to the perversion of nature in the Roman villa. The Epicurean landscape, for Lucretius, symbolizes the correct way of living, free of luxuria. ${ }^{18}$ Ann Kuttner has written on the purpose of the frescoes of the Roman garden room to domesticate - and, consequently, dominate - nature. ${ }^{19}$ Longus, though, notes the many problems of pastoral life, beginning with the potential wolves $(1,20,4)$ and biting flies $(1,23,3)$. Techne, as when Chloe becomes more beautiful with make-up, will ultimately be preferred to phusis. ${ }^{20}$ At the same time, Longus concludes the novel by refusing fully to authorize civilization, as Daphnis and Chloe bring their goats into the city, much to the consternation of their neighbors $(4,38,4)$. Daphnis and Chloe not only continue in their cultic devotion to the ritual site of the spring, but they emulate their own upbringing in having goats suckle their children.

\section{The Spring as Egalitarian Motif}

\section{A Chloe's Association with the Spring}

As the prologue establishes that the spring sustains everything in the idealized garden of Longus, Chloe's association with the motif of springs serves as the mechanism by which Longus destabilizes and reconfigures gender roles throughout the novel. The spring is a liminal space in which she can explore the bodies of both herself and Daphnis outside normal gender expression. It creates a reciprocal relationship between Chloe and Daphnis. The spring's constancy in its connection with her resists the competing demands from the pastoral and civilized spheres, bringing forth the imaginative space in which a less patriarchal union can be created and nurtured.

The spring by which Chloe was abandoned witnesses the beginning of erōs when Chloe gazes on Daphnis' bathing body in the Nymphs' cave. ${ }^{21}$ This devel-

17 Saec. 4,2,27-32 and 4,3,10-12; Lucr. 2,20-33.

18 Newlands 2002, 130.

19 Kuttner 1999b. See also Mittelstadt 1967.

20 Goldhill 1995, 64, 107, discusses Roman moralists' excoriation of women for wearing makeup. In Xenophon Oic. 10, the new bride is chided for wearing make-up and high heels like a slave. See Goff 2004, 135.

21 Goldhill 1995, 9-11. 
opment has been presaged in the novel in the dream revelation received by both Lamon and Dryas depicting Daphnis and Chloe being handed over by the Nymphs to an unidentified winged boy - the site is the spring 'where Dryas had found the baby' $(1,7,2)$. In order to avoid parental censure for having a minor escapade in their pastoral duties that involved Daphnis falling into a pit, the pair go to the Nymphs in order to wash the mud off Daphnis' body $(1,12-13)$. As Chloe watches Daphnis bathe, he seems beautiful to her for the first time. She thinks the bath must be the cause of his newfound beauty, and she tests her hypothesis as she washes his back. Longus suggests her desire is one of similarity in body: Chloe feels Daphnis' skin to see if it is softer than hers $(1,13,2)$. Longus departs from such marital models as the Homeric like-minded marriage between Odysseus and Penelope, where Penelope's bed-trick forces Odysseus to reveal his identity. Longus instead emphasizes that the basis of the erotic relationship between Daphnis and Chloe is the tactile similarity of their bodies, empirically discovered by Chloe as she touches Daphnis. ${ }^{22}$ Where Penelope waits for epistemological enlightenment from Odysseus, Chloe actively constructs her fields of knowledge scientifically.

The idyllic setting prevents Daphnis and Chloe from questioning the appropriateness of their actions. Social anxieties concerning the bath were manifested in myriad myths concerning violations of female bathing: the violation of Susanna's bath by two prominent men in Susanna and the Elders; the unintended disturbance of Artemis' bath by Aktaion; the blinding of Erymanthos, son of Apollo, for chancing upon Aphrodite in the bath; the lusting of Hermas after his mistress Rhoda bathing in the Tiber in the Shepherd of Hermas. The thrust of these myths, though, is not to restrict women's mobility by implying that they are under constant threat from male sexuality. Instead, in each of these stories, the sanctity of a woman's bath, even when it is in the public sphere, such as a river or a spring, is upheld. Such is the assessment of Quintilian, who acknowledges the potential for misunderstanding mixed bathing - men and women bathing together - as promiscuous behavior liable to result in adultery. He dismisses this line of reasoning on the grounds that if mixed bathing were considered promiscuous behavior, then so too could reveling with youths and having intimate friendships with men be considered grounds of adultery (Inst. Orat. 5,9,14). Some of this salacious activity might have involved prostitutes, but there are also sources such as Martial's epigram relating Galba's desire to marry Martial (11,19). Juvenal's satire of the practice of mixed bathing as a venue for the genital stimulation of ma-

22 For the problematic nature of touching in Greek literature, see Carson 1990, 135. 
trons is further confirmation of its popularity as a healthy activity bordering between the respectable and the risqué. ${ }^{23}$

Premarital mixed bathing, of course, is not perceived as a problem in Daphnis and Chloe. Chloe's empowerment over traditional gender performance continues in her subsequent ablutions of Daphnis. After the burial of Daphnis' rival Dorkon, Chloe takes Daphnis to the Nymphs and bathes him. Chloe keeps her kiss with Dorkon secret. She re-establishes a unique erotic relationship with Daphnis by bathing in front of him for the first time. In both the contemporary Christian text of Ephesians and Ovid's version of the festival of Venus, Verticordia, a bath functions to wash blemishes off the body of the woman in the eyes of a man - in Ephesians, the husband washes the blemishes off his wife (5,26-27); in the cult of Venus Verticordia, the women wash the blemishes off themselves and adorn the cult statue with garlands (Ov. Fast. 4,133-160). Chloe, naturally, does not need the bath to remove blemishes - the bath made Daphnis kalos to Chloe, and it was a kiss that enflamed the heart of Daphnis. The pair offers flower garlands for Dorkon to the Nymphs. Chloe's character seems to have derived some of the benefits associated with female bathing rituals and customs, while escaping such potential pitfalls as the imputed presence of blemishes.

The flow of Longus' narrative places Chloe's bath, a significant development in Daphnis and Chloe's relationship, between two narrative events connected with Daphnis' dead rival $(1,32,1)$. Chloe does not go as far as Daphnis will go with Lykainion, but she has a sexual secret of her own, one that she has made consciously. Moreover, this incident follows Chloe's removal of her breastband to give to a cowherd recruited from a neighboring farm $(1,12,4)$. The breastband is charged with eroticism, particularly since a series of erotic representations found among Fourth Style wall-paintings (62-79 CE) feature women naked save for a breastband. ${ }^{24}$ On the one hand, Chloe's removal of her breastband prepares her for a sexual relationship with Daphnis in a manner that reminds one of Martial's comment to his wife that 'a girl cannot be naked enough' $(11,104,7-8)$. This is a play on the motif of Aphrodite/matron (un)tying her breastband at her bath, found from the Hellenistic to imperial Roman periods. ${ }^{25}$ On the other hand, Chloe hands the breastband not to Daphnis, but to a cowherd, who extends it to Daphnis. Theorizing on the nature of striptease, Barthes has observed that removing elements of clothing reinscribes 'nakedness as a natural vesture of woman, which amounts in the end to regaining a perfectly chaste

23 Ward 1992, 134-138.

24 Stafford 2005, 106.

25 Stafford 2005, 107. 
state of the flesh'. ${ }^{26}$ Here, Chloe's action of removing her breast-support highlights the artifice and techne that it is, as the strip of cloth can also literally serve as a hoisting device. One wonders about the identity of Longus' intended audience: would elite male readers really be consoled at the thought of their female counterparts sharing kisses with their romantic rivals and, as Dorkon is a cowherd rather than a mere goatherd, social betters?

But the spring does not only enhance Chloe's agency; it also constructs Daphnis as a passive hero, the fundamental protagonist of the Greek novel. ${ }^{27}$ During the Methymnean raid, Chloe takes Daphnis to the Nymphs 'very quietly' (pollèn hèsuxian) in order that she may wash the blood off his face, feed him, and kiss him $(2,18)$. In contrast, Daphnis looks for Chloe in the 'quiet' (hèsuxias) of the post-raid plain $(2,21,2)$. Upon discovering she has been taken as booty, he resolves either to die or to wait until the next war. ${ }^{28} \mathrm{He}$ then visits the spring to accuse the Nymphs, who offer to intercede for him with Pan $(2,23,4)$. Similarly, after the flowers of Daphnis' spring have been destroyed in the wake of Lamon's cleaning of them, the family mourns his impending punishment by the master, and Chloe envisions him already being flogged (4,9,1). Daphnis' encounters with springs underscore his social vulnerabilities.

Chloe, of course, shares these vulnerabilities. The springs of the novel do not act as a utopian or apotropaic refuge for her-after all, she is abducted by pirates at the Grotto of the Nymphs. As Daphnis must succeed where Pan has failed, by getting the girl, Chloe must learn to choose more strategic geographic locations than Syrinx when in duress. In Book Two, after Lamon's story about Pan and Syrinx and Philetas' song, Longus' narrative tells us that all syrinxes are represented by one syrinx $(2,35,4)$. Chloe then enacts the role of Syrinx to Daphnis' Pan, but, instead of fleeing to a marsh, she hides in the woods $(2,37,2)$. The importance of this innovation does not become clear until Book Four, in the scene where Daphnis entertains the large crowd, including Gnathon, by playing the syrinx. Chloe, upon seeing the crowd approach, has already fled into the woods. Perhaps this timidity is an illustration of Bourdieu's argument that women, of necessity, are better than men at reading non-verbal, non-explicit cues. ${ }^{29}$ Chloe has never been completely protected from the dangers of the opposite sex in Longus' ideal landscape. During the pirate raid of the first book, Chloe is safe because she was driving Dryas' sheep out more slowly, due to her fear of the headstrong shepherds $(1,28,2)$.

26 Barthes 1972, 85.

27 Konstan 1994, 15-36.

28 Iamblichos' Babyloniaka features men who kill themselves freely.

29 Bourdieu 2001, 31. 
In any event, Chloe's response contrasts with the uncharacteristic boldness of Daphnis, who here manages to play an aggressive, masculine role in entertaining the crowd in the hopes of being rewarded with marriage to Chloe. He will later emulate her approach-albeit in his own suicidal manner, by running toward the sea to cast himself off a cliff-when Astylus and a large crowd run toward him to give him the glad tidings that he is the son of Dionysophanes and the brother of Astylus $(4,22,2)$. Hiding in the woods, of course, would have been the wiser action for Daphnis, as the woods would have concealed him from Gnathon's gaze and taken him back to the site where he learned how to perform the 'work of love' from Lykainion. Paradoxically, the woods are a site of agency as much as they are the site of hiddenness. ${ }^{30}$ The ideal spring in the novel is a site of civilization, which is a negotiated space and, as such, never a safe haven.

Though both Daphnis and Chloe interact with the spring, the narrative codes the spring as Chloe's. Chloe is the only one of the pair to be nursed in the Nymphs' cave. When Daphnis and Chloe dedicate their pastoral items at the cave at the conclusion of their pastoral life, Daphnis takes a drink from the spring because he had often done so on his outings with Chloe. Longus thus portrays Daphnis as the object of Chloe's gaze at the spring both literally and in remembrance $(1,12-13 ; 4,26,4)$. Chloe pours wine into the spring because she had been nursed by it and bathed in it $(4,26,4 ; 4,32,3)$. Lykainion's instruction to have Chloe bathe in the spring to remove the blood of defloration is thwarted when the narrative progresses to Daphnis swimming in rivers and Chloe bathing in springs $(3,24,2)$.

\section{B Daphnis' Association with Flowers}

To complement Chloe's connection with the spring, Daphnis is associated with flowers. The metaphors of the novel thus take 'literally', in the manner of de Certeau's notion of social delinquency, the worries of Chloe's mother that Chloe will give up her virginity for apples or roses. ${ }^{31}$ In the Prologue, the flowers are subordinated to the sustaining spring. Likewise, Daphnis' association with the flowers watered by the spring in the subsequent narrative serves to subordinate him to Chloe. ${ }^{32}$

30 Kestner 1973, 171.

31 For Greek cultural associations of maidens with fruit, see Carson 1990, 145-148.

32 Daphnis also assumes other typically feminine imagery, such as being a talkative cricket $(1,17,4)$. 
Daphnis' floral connection is made clear first by the comparisons of the novel. When Chloe laments her lovesickness after seeing Daphnis in his bath, she compares Daphnis to flowers. In the contest with Dorkon for a kiss from Chloe, Daphnis himself compares himself to flowers. To win his suit, Dorkon has claimed that Daphnis is 'beardless like a woman' $(1,16,2)$. Daphnis is at a disadvantage against Dorkon in age, since Dorkon used to shepherd with Chloe's adopted father. Daphnis therefore likens both his beardlessness and his skin to the hyacinth and announces that Dionysos shares this attribute. Moreover, there is a hierarchy of flowers - the hyacinth is better than the lily, for example - and so Daphnis' perceived softness is of the very best kind. Chloe crowns Daphnis' head with violets and kisses his hair, which she thinks is better than the violets. This might be a literary allusion to Odysseus' hair when he woos Nausikaa and his own wife Penelope. ${ }^{33}$ In Roman literature, violets symbolize beautiful yet fragile virginity and love. ${ }^{34}$ In the Lament for Bion, the hyacinth chatters in sorrow at the death of the beautiful flute-player. The resemblance of Daphnis to flowers both underscores his heroic beauty and threatens to tear the lovers apart.

As the narrative progresses, Daphnis soon becomes quite literally and inextricably linked with the fate of flowers. When Lampis realizes that Daphnis will be the one to wed Chloe if the master consents, Lampis ruins the flowers in Daphnis' master's park in an attempt to implicate Daphnis in the crime. Daphnis' father, Lamon, has just cleaned the springs for his master's arrival. The family proceeds to mourn for the flowers, 'a novelty' $(4,8,1)$. Throughout the novel, Daphnis' association with flowers endows him with a vulnerability corroborated by his near abduction by a socially superior suitor and his helpless weeping at Chloe's actual abduction by a rival.

\section{The Spring in Relation to the Development of the Novel}

Daphnis' dominance is often seen to develop as the novel progresses to the normative urban marriage at its conclusion. Two aspects in particular have been interpreted as introducing Daphnis to his proper patriarchal moment as a man. First, Daphnis' education of Chloe places him in the husbandly role of instructor established since Xenophon's Oikonomikos, though Chloe is, unusually, only two years younger than Daphnis. Second, the apple-picking scene, where Daphnis re-

33 Od. 6,231; Od. 23,157-162.

34 Cf. Ovid Met. 5,392; Pliny Hist. Nat. 21,38,4. 
trieves an apple for Chloe against her wishes, confirms him as the dominant, decision-making patriarch. I will suggest that these scenes give Chloe agency: she initiates kisses beyond Daphnis' requests, and she demands that Daphnis pay her due attention. They do not establish a patriarchal, asymmetrical relationship between Daphnis and Chloe.

\section{Daphnis' Education of Chloe}

At the conclusion of the novel, Daphnis 'does Chloe some of what Lykainion had taught him'. This is often taken by interpreters to signify Daphnis' assumption of the traditional pedagogic role of the husband. ${ }^{35}$ However, the verbs applied to Daphnis and Lykainion differ - Daphnis does (edrase), but Lykainion originally taught (epaideuse) the act $(4,40,3)$. Thus, Daphnis does not become the teacher any more than he has truly become the wolf after a lupine liminal experience from childhood into adulthood. Up to this culminating point, the narrative has consistently undercut the reader's perception of Daphnis' exclusive knowledge.

The introduction of the erotodidaskalos Philetas near the beginning of the second book is one of the fundamental moments of pedagogy. Longus' Philetas shares his name with the grammarian who penned Akatoi glōssai. It is from Philetas that the young couple acquires a name to apply to Erōs: 'they heard for the first time the name of Love' $(2,8,1)$. The concern for the name of Erōs is as much semiological as it is religious and practical. ${ }^{36}$ Indeed, Daphnis' and Chloe's adopted parents have already had dreams with Love in them, and, though the pair is still entrusted to Love, they will not need to pay the god any type of obeisance. Their lexical education will not produce enlightenment as to how to satisfy their desire for one another. Daphnis and Chloe instead emulate in their confusion the example of Philetas the grammarian, who wasted away in a search for the 'fallacious logos'. The scene establishes Philetas as the teacher.

The novel's conclusion gives Chloe knowledge superior even to the authorial voice, which informs the reader that Daphnis and Chloe stayed up as late as owls in the wedding chamber. Longus' choice of the owl comparison is curious, for it resumes the description of the couple in pastoral language that the authorial voice has declared to be over. Even more peculiar is that Chloe learns that

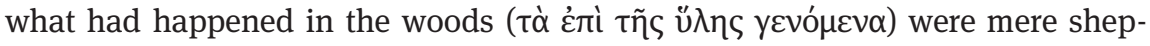
herd's games. As the majority of Daphnis and Chloe's romantic activity has oc-

35 Winkler 1990, 124; Epstein 1995, 70; Morgan 2004, 12.

36 Whitmarsh 2005, 147. 
curred in the fields and the Grotto of the Nymphs, the woods should be taken as the site of the romantic overtures of Dorkon and Lykainion. In the winter, Daphnis makes the same request of Chloe that the dying Dorkon did: to remember him. Chloe reassures Daphnis by swearing that she does remember him, swearing by the Nymphs of the Grotto, where they will return once the Scythian snow melts.

Civilization and cultivation are signified by the marriage - Chloe and Daphnis entered the wedding chamber to an epithalamium that sounded as though the singing wedding party were breaking the ground with pitchforks. Greek literature typically presents the bride as a wild location that needs to be cultivated by the husband and the coital act as corresponding to the verb 'to hoe' ( $\sigma \kappa \alpha \lambda \varepsilon u$ $\varepsilon(v) .{ }^{37}$ Accordingly, the reader may think of the tryst between Lykainion and Daphnis as a 'mere shepherd's game', a game that is not appropriate to Daphnis' newly elevated social status. Chloe's own perspective on the loss of her virginity contradicts Lykainion's prognostication. With her new education, Chloe has tri-

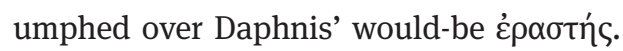

\section{Springs as Symbols of Hospitality and Civilization}

Ultimately, Chloe and Daphnis mature from country- to urban-dwellers through the tutelage of the text. So, too, do springs expand into a symbol of broader hospitality and civilization. Five characters have a connection with bathing in springs in the novel: Daphnis, Chloe, Philetas, Dorkon, and Lykainion. Daphnis and Chloe are the chosen pair of Eros, whose shepherding role is embodied by Philetas. After the initial she-wolf encounter leads Chloe to bathe Daphnis in the spring, the two human 'wolves' in the story, Dorkon and Lykainion, challenge this arrangement. The spring develops the generosity of hospitality, as Dorkon is rehabilitated, and the values of civilization, as Lykainion is not.

\section{A Dorkon's Redemption}

Dorkon is redeemed authorially by being washed in the spring by the lovers, who remain unaware of his transgression. As his dying act, Dorkon saves the life of

37 For betrothal formulas, see Clement of Alexandria Strom. 2,23, and Menander Pk. 435. For sexual intercourse, see Aristophanes Pax 440 and Ec. 611. See Carson 1990, 149. 
his romantic rival in exchange for a kiss and a promise to remember him. Daphnis and Chloe proceed to pay homage to his memory at the spring in the Nymph's cave. Thus, the spring sustains Dorkon's rehabilitation into society and worship of the gods. Since other incidents, such as the Methymnean driving of Chloe and goats from the cave, seem to indicate a choice in piety, the novel represents an optimistic viewpoint on human relations: enemies need not remain so in light of the civilizing influence of the spring $(2,20)$.

\section{B Lykainion's Pedagogy}

Lykainion does not bathe in the spring nor is she redeemed as the male characters Dorkon and Gnathon are. She is present at Daphnis and Chloe's wedding with her husband, but this is inconclusive as evidence of her character, since Lampis is also present (4,38,2-3). Interpreters such as Konstan and May have taken Lykainion to be a sympathetic character. ${ }^{38}$ However, Epstein observes that Lykainion's teaching has an element of Pan. ${ }^{39}$ She is a stock character also found in Leucippe and Clitophon, where Clitophon tells Melite that it would be unsuitable to consummate their marriage on a moving bed $(5,16)$, a clear play on the trope of Odysseus' famously immovable bed. Lykainion and Melite belong to the long-established tradition of the predatory woman, well known since Euripides' treatment of Phaedra and Hippolytos. ${ }^{40}$ However, in Daphnis' case, Lykainion represents real danger, as she, an elite woman, is asking a slave to commit adultery with her, an offense which in plays such as Miles gloriosus carries threats of castration (1398-1399). Though a woman, Lykainion has a class advantage on Daphnis that far outweighs Dorkon's superiority over Daphnis and Chloe, due to his shepherding of cows instead of goats. This makes her analogous to the upper-class wives in Juvenal's sixth satire who have affairs with men of lower classes. ${ }^{41}$ She should not be sexually available to the slave Daphnis. Nonetheless, despite her privileged social and sexual positions, the novel gives Lykainion an advantage over neither Daphnis nor Chloe.

True to her 'little wolf' moniker, Lykainion suggests that Daphnis bring Chloe to the spring, take her virginity where no one can hear her screams, and have her bathe the blood off in the spring. Such an action would transpire outside of the community. Daphnis, who has previously insisted to Chloe that

38 Konstan 1994, 54; May 2005, 132.

39 Epstein 1995, 70; Epstein 2002, 72.

40 For Phaedra, see Zeitlin 1996, 219 - 284.

41 On Juvenal, see Smith 2005, 119. 
doing 'everything he wanted' would 'conquer the bitterness of love' $(3,14,3)$, now cringes at the thought of Chloe bleeding and yelling at him as if he were an enemy $(3,24,3)$. If, as Carson notes, civilization is a function of boundaries and anthropologists have correctly observed that 'every touch is a modified blow', then Daphnis is reassessing the norms of civilization and the violence therein. ${ }^{42}$ Pain, as evidenced by the Spartan practice of commemorating by tomb inscription only male death on the battlefield and female death in childbirth, was culturally perceived as inevitable and even beneficial. ${ }^{43}$ It is the thought of turning Chloe into an enemy that gives Daphnis real distress.

Lykainion's proposal inhabits the marginal spatiality of maenadism, which is a state diametrically opposed to marriage in ancient Greek consciousness. ${ }^{44}$

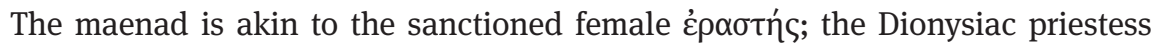
pays to initiate worshippers 'in the city, in the country, in the islands' (LSAM 48,18-19, an early third-century inscription from Miletos on the priestess' responsibilities). Lykainion is behaving as a maenad in the no-man's-land territory of a maenad, and she has used gifts to initiate Daphnis in order to induce him to induct Chloe likewise into maenadism, outside the conventions of marriage.

The patriarchal message undergirding Lykainion's admonition - that male desire is a desire to harm, to conquer - is particularly dire in the opinion of Winkler: 'Nevertheless, the content of Lykainion's warning, even if the context shifts it into an ironic mode, is grim' ${ }^{45}$ In response to Winkler, Goldhill suggests Daphnis' naivete erects him as a positive exemplum: 'Is not part of the joke precisely that Daphnis does take the message to heart and that that is a sign of pastoral

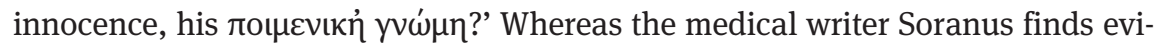
dence of the voracious female sexual appetite even in the instance of rape, in Goldhill's reading, Daphnis interrogates his masculine desire lest it be deleterious to the object of his desire. Love, for Daphnis, seeks what is best for the beloved. ${ }^{46}$

In Daphnis' aversion to conceptualizing Chloe in violent metaphors, Longus presents a subtle critique on the warfare topoi prevalent across genres, including that of the ancient novel, with a focus on love. ${ }^{47}$ The sensuality of Callirhoe's bathing body is indicated by the fear that touching her might inflict a 'bad

42 du Bois 1988; Carson 1990, 135.

43 Plutarch Lyc. 27,2-3; King 1999, 274-276.

44 Seaford 1995, 301-11; Goff 2004, 278.

45 Goldhill 1995, 35.

46 Goldhill 1995, 39.

47 Smith 2005, 82, provides an overview of warfare imagery in Roman erotic literature. 
wound' ${ }^{48}$ Lucretius compares the attraction one feels toward a beautiful body with falling toward a wound. ${ }^{49}$ Ovid declares 'every lover is a warrior' and depicts the sleeping husband as the enemy. ${ }^{50}$ In Ninos, the eponymous protagonist protests to his beloved's mother that her daughter has made him a 'prisoner of war-an honorable captivity, of course'. ${ }^{11}$ Daphnis is so steadfast in his desire not to hurt Chloe that he stops seeking to have her lie next to him naked, and finally pursues her hand in marriage only when it becomes apparent that her parents will marry her off to another who will have no such qualms..$^{52}$ The relationship of a man and woman, for Longus, can be positively expressed through fruit metaphors, but not through warfare metaphors. A man and a woman are not enemies; they are partners against life's real threats.

The spring thus represents Chloe's privileged status as a protagonist of the novel. Daphnis' mother Myrtale is persuaded that Chloe might want a handsome young husband rather than a rich one $(3,26,4)$. Lykainion is in an unequal marriage: her aged spouse has come to farm his own land in the country, while she is still young and pretty. Lykainion does not obtain a lengthy, torrid love affair but a 'one-spring stand'. If she wants to continue to supplement her elderly husband's deficiencies, she will have to repeat the process of investigation and outlay of economic goods in exchange for sensual pleasures. ${ }^{53}$

Chloe is privileged again by the novel when Lykainion's plan for Chloe to have a singular sexual encounter with Daphnis - as opposed to the coveted marriage to an equal - is thwarted by the progression of the narrative toward aquatic recreation. Daphnis proceeds to swim in the rivers, while Chloe proceeds to bathe in the springs. From the first book of the novel, we know that the only difference between these two actions is the topographical feature: Daphnis bathes (and incidentally hunts circularly swimming fish) when he is swimming in rivers. Interpreting these through the narrative framework, there could be a seasonal aspect and an implication of the cycle of life, recurring motifs in the novel (cf. 2,3,4). From an anthropological vantage point, swimming in rivers is part of an initiation ritual in a report by Euanthes, read by Varro and found in Pliny. ${ }^{54}$ In an Arcadian family descended from Anthos, a young boy, selected by lot, had to re-

48 Hunter 1993, 1074-5.

49 Lucr. 4,1049-1057.

$50 \mathrm{Am} .1,9,1 ; 1,9,25-26$.

51 A, II,27-31.

52 Konstan 1994, 88.

53 Stephen and Winkler 1995, 347, correlate Lykainion's behavior with that of Persis in Phoinikika.

54 Nat. 8,81. 
move his clothes, swim across a lake, and become a wolf for eight years. If he successfully managed to avoid eating human meat, he was allowed to swim back and resume his human existence, now as a grown man. Epstein has posited that the liminal period suggested by this Spartan myth serves to form the ephebe into a new corps for the Spartan military corporate body. ${ }^{55}$ By contrast, Daphnis, by swimming circularly, is not orienting himself in the normal expansiveness of ancient men. He masters the circular fish within the river without needing to cross over to the other side to become a wolf.

Longus' thwarting of Lykainion also reverses associations found in other second century myths. Pausanias recounts a story with the same association of rivers as male and springs as female. In it, the hunter Alpheus falls in love with the huntress Arethusa. Unwilling to marry, Arethusa swims to the island Ortygia and turns into a spring in order to escape Alpheus' advances. However, the outcome of Pausanias' tale is entirely different. Alpheus wins in the romantic struggle, since he is able to turn into a river which can mingle with Arethusa's spring. ${ }^{56}$ The geographical consequences of unrequited love in Pausanias' version are almost identical to Ovid's tale of the river-god Acheloos' lapping his streams against a nymph-turned-island. A recognition of the danger for the female in this motif can be found in the Greek novel Leucippe and Cleitophon, where the hero Cleitophon enumerates four examples of eros in nature. After deeming the flowing together of Alpheus and Arethusa a marriage (gamos), the hero explains that in the mating of the land-snake and the water-snake, 'the continental lover and the island beloved', the land-snake must eject the poison from his fangs before kissing the water-snake $(1,7)$. Through the motif of the spring, Daphnis and Chloe subvert both the asymmetrical relationships of wealthy women and slave found in the satirists and New Comedy, and of victorious man and conquered woman related by Ovid and Pausanias. ${ }^{57}$

\section{Politics of the Spring}

The final moral of the novel is: live in the city, but be not 'of the city'. The idealized bucolic values are connected to the cave, the nymphs, and the spring. This may be seen in the scene where Daphnis dedicates his pastoral items, speaks

55 Epstein 1995, 72.

56 Paus. 5,7,2-3.

57 Konstan 1994, 85. 
with the goats, and drinks from the spring. The narrative function of the spring is to critique the value-system of civilization traditionally defined.

Militaristic and imperialistic topoi saturate Longus' historia. The novel commences with a suckling she-wolf, traditionally a symbol for Rome, destroying livestock. The central political incident is the Methymnean invasion, where the militaristic trumpet plays on pastoral pipes. Daphnis initially believes that doing 'everything he wanted' would 'conquer the bitterness of love' $(3,14,3)$, though he desists from this pursuit because he does not want Chloe to look at him as though he were an 'enemy'. Warfare imagery also features in Lykainion's instructions to Daphnis. Captain Bryaxis' dream from Pan rescues the captured Chloe. Militaristic intervention is necessary again when Gnathon has a 'great victory' rescuing Chloe and is eager to tie up Lampis as a 'prisoner of war' $(4,29,3)$. After refusing to employ the warfare metaphors common in erotic literature, Longus suggests the juxtaposition of political and pastoral by the new titles of 'Soldier' for Pan and 'Shepherd' for Eros at the end of the novel.

Ultimately, this division is not a dichotomy. Pan, with his theriomorphism and war, does not exist in isolation from the Nymphs, with their spring and civilization. Daphnis and Chloe demonstrate the pedagogic value of the interplay of the spring and the flock by using sheep and goats to nurse their children, Philopoemen and Agele, in the city $(4,39,2)$. The Temple of Pan appears to be unique to Longus, and indicates bringing Pan in from the periphery. ${ }^{58}$ In the protagonists' mutual negotiation of a socially acceptable relationship in which the male is modeled on Pan/Dionysos and the female is modeled on the Nymphs, both husband and wife gain authority in the socioreligious order of Longus' moral vision. As in the Roman notion of emulatio, the young lovers improve on the examples of Pan and the Nymphs in their mimesis.

\section{Conclusion}

In Daphnis and Chloe, the phrase 'philesai philousan' ('to love a woman who loves in turn') is paradigmatic. ${ }^{59}$ Given the gender inequalities pervading the contemporary culture, Longus' technique for effecting mutuality in desire and its expression is to create a relation of motifs that privilege the female in order to resist cultural impulses toward patriarchy. Longus highlights the vestiges of the voices belonging to those dismembered by patriarchy: the nightin-

58 Morgan 2004, 248.

59 Konstan 1994, 35. 
gale, the swallow, and Echo. Men and women, however, need not be at war even metaphorically; they may partner together against actual threats from pirates, Methymneans, and even their own neighbors. Thus, Chloe is associated with the central motif of the spring and the Nymphs, and Daphnis is allied with the flowers sustained by the spring and Pan/Dionysos. Participation of parental figures such as Lamon and Philetas in the maintenance and enjoyment of the spring sanction the marital and civic valences of the topos. Chloe and Daphnis utilize the spring to circumvent and rehabilitate rivals, occasionally with negotiation of topoi associated with Pan. Raising their children at the spring, they attempt to replicate their own liberating education in order to have people with whom to grow old. This mimesis does not include their neighbors, who remain rehabilitated by the spring but not initiated into and sustained by it. In these ways, the symbolism of the spring occupies the interstices of narratological relations and Longus' timeless message.

\section{Bibliography}

Anagianou, A. 1991. Sacred Marriage in the Rituals of Greek Religion, Berne: Peter Lang. Barthes, R. 1972. Mythologies (A. Levers, trans.), New York: Hill and Wang.

Bourdieu, P. 2001. Masculine Domination (R. Nice, trans.), Stanford: Stanford University Press.

Bowie, E. 2005. 'Metaphor in Daphnis and Chloe', in: S. Harrison, M. Paschalis, S. Frangoulidis (eds.), Ancient Narrative: Metaphor and the Ancient Novel, Groningen: Barkhuis. 68-86.

Boyarin, D. 1997. Unheroic Conduct: The Rise of Heterosexuality and the Invention of the Jewish Man, Berkeley: University of California Press.

Brethes, R. 2007. 'Poiein Aischra Kai Legein Aischra, Est-ce Vraiment La Même Chose ? Ou la bouche souillée de Chariclée', in: V. Rimell (ed.), Seeing Tongues, Hearing Scripts:

Orality and Representation in the Ancient Novel, Groningen: Barkuis, 223-256.

Burkert, W. 1983. Homo Necans: The Anthropology of Ancient Greek Sacrificial Ritual and Myth (P. Bing, trans.), Berkeley: University of California Press.

Burrus, V. 2005. 'Mimicking Virgins: Colonial Ambivalence and the Ancient Romance', Arethusa 38, 49-88.

Carson, A. 1990. 'Putting Her in Her Place: Woman, Dirt, and Desire', in: D.M. Halperin, J.J. Winkler, F.I. Zeitlin (eds.), Before sexuality: the construction of the erotic experience in the ancient Greek world, Princeton: Princeton University Press. 135-169.

Chalk, H.O. 1960. 'Eros and the Lesbian Pastorals of Longos', JHS 80, 32-51.

Chew, K. 2007. 'Divine Epistemology: The Relationship Between Speech and Writing in the Aithiopika', in: V. Rimell (ed.), Seeing Tongues, Hearing Scripts: Orality and Representation in the Ancient Novel, Groningen : Barkuis, 279-298. 
D’Ambra, E. 1996. 'The Calculus of Venus: Nude Portraits of Roman Matrons', in: N.B. Kampen (ed.), Sexuality in Ancient Art: Near East, Egypt, Greece, and Italy. Cambridge: Cambridge University Press. 219-232.

de Certeau, M. 1984. The Practice of Everyday Life, Berkeley: University of California Press. du Bois, P. 1988. Sowing the Body: Psychoanalysis and Ancient Representations of Women, Chicago: University of Chicago Press.

Epstein, S. 1995. 'Longus' Werewolves', Classical Philology 90, 58-73.

Epstein, S. 2002. 'The Education of Daphnis: Goat, Gods, the Birds, and the Bees', Phoenix $56,25-39$.

Faraone, C. 1990. ‘Aphrodite's KESTOS and Apples for Atalanta: Aphrodisiacs in Early Greek Myth and Ritual', Phoenix 44, 219-243.

Gilhuly, K. 2009. The Feminine Matrix of Sex and Gender in Classical Athens, Cambridge: Cambridge University Press.

Goff, B. 2004. Citizen Bacchae: Women's Ritual Practice in Ancient Greece, Berkeley: University of California Press.

Goldhill, S. 1995. Foucault's Virginity, Cambridge: Cambridge University Press.

Hawkins, T. 2009. 'This is the Death of the Earth: Crisis Narratives in Archilochus and Mnesiepes', TAPA 139, 1-20.

Hunter, R. 1993. 'History and Historicity in Chariton', ANRW II.43.2, 1055-1086.

Kestner, J. 1973. 'Ekphrasis as Frame in Longus' Daphnis and Chloe,' Classical World 67, $166-171$.

King, H. 1999. 'Chronic Pain and the Creation of Narrative', in: J.I. Porter (ed.), Constructions of the Classical Body, Ann Arbor: University of Michigan Press. 269-286.

Konstan, D. 1994. Sexual Symmetry: Love in the Ancient Novel and Related Genres, Princeton: Princeton University Press.

Kuttner, A. 1999a. ‘Culture and History at Pompey’s Museum', TAPA 129, 343-373.

Kuttner, A. 1999b. 'Looking Outside Inside: Ancient Roman Garden Rooms', Studies in the History of Gardens and Designed Landscapes 19.1 [special issue, J. D. Hunt (ed.), The Immediate Garden and the Larger], 7-35.

Lissarrague, F. 1990. 'The Sexual Life of Satyrs', in: D.M. Halperin, J.J. Winkler, F.I. Zeitlin (eds.), Before sexuality: the construction of the erotic experience in the ancient Greek world, Princeton: Princeton University Press. 53-81.

Littlewood, A.R. 1968. 'The Symbolism of the Apple in Greek and Roman Literature', HSPh 72, 147-181.

Luginbill, R.D. 2002. 'A Delightful Possession: Longus' Prologue and Thucydides', CJ 97, 233- 247.

MacQueen, Bruce. 1990. Myth, Rhetoric, and Fiction. Lincoln: University of Nebraska Press. Marinelli, P.V. 1971. Pastoral, London: Methuen.

Mason, H.J. 1995. 'Romance in a Limestone Landscape,' Classical Philology 90, 263-266.

Mattingly, D. 2011. Imperialism, Power, and Identity: Experiencing the Roman Empire, Princeton: Princeton University Press.

May, R. 2005. 'Chaste Artemis and Lusty Aphrodite: The Portrait of Women and Marriage in the Greek and Latin Novels', in: W.S. Smith, (ed.), Satiric Advice on Women and Marriage: From Plautus to Chaucer, Ann Arbor: University of Michigan Press. 129-153.

Mittelstadt, M. 1967. 'Longus: Daphnis and Chloe and Roman Narrative Painting', Latomus $26,752-761$. 
Morgan, J.R. (trans.) 2004. Longus: Daphnis and Chloe, Oxford: Oxbow.

Newlands, C.E. 2002. Statius' Silvae and the Poetics of Empire, Cambridge: Cambridge University Press.

Newlands, C.E. 1987. “Technë' and 'Tuchè' in Longus' Daphnis and Chloe', Pacific Coast Philology 22, 52-58.

Nickau, K. 2002. 'Zur Epiphanie des Eros im Hirtenroman des Longos', Hermes 130, 176-191.

Pandiri, T.A. 1985. 'Daphnis and Chloe: the Art of Pastoral Play', Ramus 14: 116-141.

Peters, J. 2009. 'Hellenistic Imagery and Iconography in Daniel 12.5-13', Journal for the Study of the Pseudepigrapha 19, 127-145.

Pratt, L. 1994. 'Odyssey 19.535-50: On the Interpretation of Dreams and Signs in Homer', CPh 89, 148-153.

Richlin, A. 1983. The Garden of Priapus: Sexuality and Aggression in Roman Humor, New Haven: Yale University Press.

Seaford, R. 1995. Reciprocity and Ritual, Oxford: Oxford University Press.

Smith, W.S. 2005. 'Advice on Sex by the Self-Defeating Satirists', in: W.S. Smith (ed.), Satiric Advice on Women and Marriage: From Plautus to Chaucer, Ann Arbor: University of Michigan Press. 111-128.

Smith, W.S. 2005. "The Cold Cares of Venus': Lucretius and Anti-Marriage Literature', in: W.S. Smith (ed.), Satiric Advice on Women and Marriage: From Plautus to Chaucer, Ann Arbor: University of Michigan Press. 129-153.

Stafford, Emma J. 2005. 'Viewing and Obscuring the Female Breast', in: L. Cleland, M. Harlow, and L. Llewellyn-Jones (eds.), The Clothed Body in the Ancient World, Oxbow: Oxbow. 96-112.

Stephen, S., and Winkler, J.J. (eds. and trans.) 1995. Ancient Greek Novels: The Fragments, Princeton: Princeton University Press.

Takács, S.A. 2008. Vestal Virgins, Sibyls, and Matrons: Women in Roman Religion, Austin: University of Texas Press.

Turner, P. 1960. 'Daphnis and Chloe: An Interpretation,' G\&R, 117-123.

Vieillefond, J.-R. (ed. and trans.) 1987. Longus: Pastorales, Paris : Société d’Édition Les Belles Lettres.

Ward, R.B. 1992. 'Women in Roman Baths', HThR 85, 125-147.

Whitmarsh, T. 2005. 'The Lexicon of Love: Longus and Philetas Grammatikos', JHS 125, $145-148$.

Winkler, J.J. 1990. 'The Education of Chloe: Hidden Injuries of Sex', in: J.J. Winkler (ed.), Constraints of Desire: The Anthropology of Sex and Gender in Ancient Greece, New York. $101-126$.

Wouters, A. 1987. 'Irony in Daphnis' and Chloe's Love Lessons', QUCC 55, 111-118.

Zeitlin, F.I. 1996. Playing the Other: Gender and Society in Classical Greek Literature, Chicago: University of Chicago Press.

Zeitlin, F.I. 1990. 'The Poetics of Erōs: Nature, Art, and Imitation in Longus' Daphnis and Chloe', in: D.M. Halperin, J.J. Winkler, F.I. Zeitlin (eds.), Before sexuality: the construction of the erotic experience in the ancient Greek world, Princeton: Princeton University Press. 417-464. 